\title{
Genetically engineered foods get green light
}

Washington. Last week the US Food and Drug Administration (FDA) embraced the principle that the government should regulate the products of genetic engineering, not the process by which they are created. Its proposed guidelines for the regulation of new varieties of foods, which had been expected for months, represent an unofficial endorsement of the idea that government agencies charged with preserving public health do not need special rules to oversee genetically engineered organisms.

The argument that such special treatment is unnecessary has been made by scientists and the biotechnology industry in several reports over the past few years*. It has not convinced environmental groups, however, which argue that the safety of the nation's food supply is being compromised by an eagerness to help companies bring new products to market.

The proposed new guidelines state that foods developed using genetic engineering pose no new or special safety risks to the consumer and should be subject to the same standards of regulation as are applied to all other foods. In a joint announcement by Vice President Dan Quayle, chairman of the president's Council on Competitiveness, and the Department of Health and Human Services (HHS), FDA's parent agency, HHS Secretary Louis Sullivan said these new technologies will provide foods "that are tastier, more varied, more wholesome and that can be produced more efficiently".

The guidelines are consistent with the line taken by the competitiveness council, which has pushed for the elimination of unnecessary regulatory burdens on the industry. They are also in keeping with similar measures introduced earlier this year to streamline the approval process for biotechnology drugs.

The guidelines put the onus on industry

officials to decide whether a new genetically engineered plant variety needs pre-market approval by FDA. FDA is the primary government agency with responsibility for ensuring safety of the nation's food supply, with the exception of meat and poultry.

Several consumer protection groups are alarmed by the notion of industry policing itself. Jane Rissler, biotechnology specialist with the National Wildlife Federation, called the policy "outrageous". "It is not protective to have a voluntary programme for an industry that is just so competitive and trying so hard to get the first products to market", she says.

At the same time, the long-awaited guidelines are welcomed by the agricultural biotechnology industry, which lags far behind other sectors of the industry and has yet to bring a genetically engineered food to market in the United States. According to the industry's trade group, the Industrial Biotechnology Association, more than 50 crops produced through genetic engineering have been tested.

Under the new guidelines, foods developed through genetic engineering, including fruits, vegetables and grains, will be regulated within the existing framework of the federal Food, Drug and Cosmetic Act. The level of oversight will be based on the characteristics of the food and its intended use, rather than the method by which it was produced.

FDA expects that many of the genealtered foods being introduced (as with most new plant varieties produced by more traditional breeding methods) will not require pre-market approval by the agency. However, pre-market approval and labelling will be required if the use of genetic engineering is shown to increase the concentration of a naturally occurring toxicant in the plant, to introduce an allergen (protein that can trig-

\section{Indian missile test fizzles out}

New Delhi. The second test of India's intermediate range ballistic missile, which the United States tried hard to prevent, ended in failure last week. The launch of the Agni was normal, according to the Indian Defence Research and Development Organisation, which developed the missile, but "its mission objectives were not fulfilled due to premature ignition and separation of the second stage". A third test, planned for next month, is expected to proceed on schedule.

India's decision to go ahead with preproduction testing of Agni is thought to be a sign to the world that the country's military missile programme, unlike its space activities, is immune from threats of em- bargo by countries that subscribe to the Missile Technology Control Regime (see Nature 357, 271; 1992). A few days before the launch, the country's defence minister, Sharad Pawar, said that India will not abandon the field even if the country is shunned by the industrialized world.

Agni, which means fire in Sanskrit, flew first in 1989. It has a range of $2,500 \mathrm{~km}$ and can carry a one-tonne payload. Its first stage uses the same solid-fuel booster as the SLV3 rocket being developed by the Indian space agency; the second stage is a twinengine, liquid-fuel propulsion system similar to what it hopes to use to launch commercial space satellites. ger an allergic response in some people) that is not commonly found in the plant or to alter the nutritional composition of the plant. Under the new guidelines, industry executives will need to pick their way through a series of "decision trees" to decide whether to consult FDA when introducing a new genetically engineered plant variety.

Predictably, the announcement was criticized by consumer protection groups, which see it as another example of the administration meddling in the affairs of the FDA. They believe that it does more to enrich the agricultural biotechnology industry than to protect consumers.

The public interest community "is getting beaten about the head", says Rebecca Goldburg of the Environmental Defense Fund. "When industry's interests differ from that of the public, the public does not win", she says.

On the day the new guidelines were announced, Jeremy Rifkin, president of the Foundation of Economic Trends and a persistent critic of biotechnology, filed a legal petition with FDA demanding that genetically altered foods be labelled as such. Rifkin wants foods containing new genetic material to be regulated in the same way that FDA regulates new food additives.

A frequent target of Rifkin's attacks, Henry Miller of the FDA's Office of Biotechnology, defends the proposed guidelines as a logical progression. He says that foods have been engineered in ways that transcend the normal barriers of reproduction for the past two decades, with genes being moved from one species to another and even from one genus to another.

One of the first genetically engineered foods to reach the grocery stores is likely to be the new Flavr Savr tomato from Calgene, Inc. of Davis, California. Researchers at Calgene have isolated from tomatoes the gene that encodes the polygalacturonase enzyme, which causes fruit to soften. Reinserting the gene into tomatoes in a reverse or "antisense" orientation blocks as much as 99 per cent of the enzyme's production.

Interested parties have 90 days to submit comments to the FDA. But barring a groundswell of public opinion to the contrary, the proposed guidelines are likely to stand.

Diane Gershon

* Field Testing Genetically Modified Organisms Framework for Decisions, Report by the US National Academy of Sciences / National Research Council, (Washington, DC, 1989); Strategies for Assessing the Safety of Foods Produced by Biotechnology, Report of a joint Food and Agricultural Organization (FAO)/World Health Organisation (WHO) consulta tion (Geneva, 1991); Exercise of Federal Oversight Within Scope of Statutory Authority: Planned Intro ductions of Biotechnology Products into the Environment, Document by the Office of Science and Technology Policy (OSTP), (Washington, DC, 1992). 